\title{
Names for Tobago
}

Arie Boomert

\section{OpenEdition}

\section{Journals}

Electronic version

URL: http://journals.openedition.org/jsa/1856

DOI: 10.4000/jsa.1856

ISSN: 1957-7842

\section{Publisher}

Société des américanistes

\section{Printed version}

Date of publication: 1 January 2001

Number of pages: 339-349

ISSN: 0037-9174

\section{Electronic reference}

Arie Boomert, « Names for Tobago », Journal de la société des américanistes [Online], 87 | 2001, Online since 17 November 2005, connection on 04 May 2019. URL : http://journals.openedition.org/jsa/1856 ; DOI : 10.4000/jsa.1856 


\title{
NAMES FOR TOBAGO
}

\author{
Arie BOOMERT *
}

The names of the islands of the Caribbean often form the oldest recorded toponyms of these islands. A good number of them owe their present name to Columbus who was profoundly concerned with the choice of names for the new world he had come across, as the act of naming symbolized taking possession. Relatively few islands have retained their original, Amerindian, name. Jamaica is an example while Haiti represents an indigenous toponym which initially applied to the entire island of Hispaniola (Taylor 1958). Tobago is one of the southernmost islands of the West Indian archipelago and at present forms part of the twin-island Republic of Trinidad and Tobago. The name Tobago is often assumed to be of Amerindian derivation, whereas its origin is actually Spanish. In fact, two now obsolete, genuinely Amerindian names are known for the island. Both were recorded in the seventeenth century. The etymology and origin of the European as well as Amerindian names of Tobago form the subject of this essay.

The first recorded name for Tobago may have been coined by Columbus. The island was probably sighted by the Admiral on August 4 or 5, 1498, when his ships were anchored in the Dragon's Mouths between Trinidad and the Paria Peninsula, close to present Punta Garcitas. According to Las Casas, Columbus spotted an island " with very high ground » 26 leagues to the northeast from this position. He called it Belaforma « because from a distance it seemed beautiful » (Las Casas 1957-1961, I, p. 357 ; Morison 1963, p. 270). Whether or not this island was Tobago, is disputed. Morison first claimed to have sighted Tobago from the top-gallant yard of his ship when sailing out of the Bocas on the track of Columbus in 1940 (Morison 1942, II, p. 261). However, afterwards he felt that he, like the Admiral, had mistakenly taken an outlying cape of Trinidad for an island (Morison 1955, p. 112 ; Morison 1963, p. 272 ; Morison \& Obregón 1964, p. 157).

Interestingly, Las Casas' abstract of Columbus' 1498 journal refers to two islands discovered by the Admiral on leaving the Dragon's Mouths on August 13 and 14. According to Las Casas, Columbus sighted an island 26 leagues to the north of the Bocas, which he named isla de la Asumpción. (It was the vigil of the Assumption of the Virgin, a feast which is celebrated on August 15.) Besides, he spotted another one Columbus called la Concepción (Las Casas 1957-1961, I, p. 368 ; Morison 1963,

* Havikweg 24, 1826 JV Alkmaar, The Netherlands. E-mail : aboomert@hotmail.com

Journal de la Société des Américanistes 2001, 87, p. 339 à 349. Copyright O Société des Américanistes. 
p. 278). The fact that the distance between Asumpcion and the Dragon's Mouths is similar to that between the latter and Belaforma, suggests that these two names actually refer to one and the same island, i.e. Tobago. Indeed, Devas (1974, pp. 10, 17-18) has identified Concepción as Grenada and Asumpción as Tobago, claiming that at sea Grenada and Tobago can be seen only from distances of 20-25 miles or less. This opinion has been accepted by Morison, who notes that Columbus apparently made a wide sweep to the east and north going out of the Bocas (Morison 1963, pp. 267, 279 ; Morison \& Obregón 1964, pp. 111, 167). However, it should be noted that on exceptionally clear days in the wet season Grenada can be viewed from high ground on Tobago's west coast, while the distance between these two islands is much larger than that between the Dragon's Mouths and Tobago (see Boomert 2000, p. 20).

Nothing is heard about Belaforma or Asumpción afterwards and from as early as 1511 Tobago appears on maps and in Spanish documents under its present name. Numerous variants of the island's name are to be found in the sixteenth-century Spanish sources. It is spelled as Tavaco in 1511 and 1512 (Jiménez 1986, pp. 129-130; Spanish Crown, $C D U$, V, pp. 258-261), as Tabacho on Ribeiro's world map of 1529, as Tabaco in 1533, ca 1545 and ca 1560 (Anonymous ca 1560 ; Oviedo ca 1545 ; Spanish Crown, in Konetzke 1953-1962, I, pp. 145-146), as Tabago on Honem's map of the Gulf of Mexico and the Caribbean dating from ca 1540, and as Tavago in 1569 (Otte 1967 , I, p. 21), to mention only the first references - the interchange of consonants in the spelling of some forms is due to the Spanish pronounciation of a $v$ as a $b$. The island remained to be called Tabaco or Tabago in Spanish throughout the seventeenth and eighteenth centuries (e.g. Gumilla, 1963, p. 43). Whereas these two forms of the name are found in late-sixteenth century English documents (Keymis 1904, p. 478), it became Tubaguo (Dudley 1646) and Tobago (Anonymous 1642) by as early as the mid-seventeenth century. The Dutch continued to use the variants Tabaco and Tabago until well into the eighteenth century (e.g. De Laet 1931-1937, II, p. 21 ; Rochefort 1665). While in the mid-seventeenth century French sources refer to Tobago as Tabuco or Tabac (Breton, 1999, p. 204 ; Moquet, cited by Nardin 1962), until recently the French, like the Spanish, still spoke of Tabago rather than Tobago ${ }^{1}$.

Origin and meaning of the name Tobago have been the subject of a long-lasting discussion. As is indicated by its sixteenth-century variants, the original name of the island was undoubtedly Tabaco, i.e. the Spanish word for "tobacco ". The noun tabaco has remained unvaried in Spanish throughout the centuries ; it is comparable to derivates such as modern French tabac and Dutch tabak. The seventeenth-century English alteration from Tabaco or Tabago to Tobago is reflected by the vowel change from tabaco to tobacco in this language. The latter variant is undoubtedly related to the Dutch noun toebak, a now obsolete form which is synonymous to tabak. Unfortunately, the origin of the Spanish word tabaco is often misunderstood. Tobacco (Nicotiana rustica and N. tabacum) is an indigenous cultivar of tropical America which the Spanish as the first Europeans only learned to know as a result of Columbus' voyages to the West Indies. It is frequently assumed that together with knowledge of the tobacco plant the Spanish adopted the term tabaco as a loanword from Taino, the Arawakan language of the contact-period Amerindians of the Greater Antilles 
(Brinton 1871 ; Friederici 1960, pp. 576-580, 769-770 ; Furst 1992 ; Lovén 1935, p. 393 ; Oxford English Dictionary 1971, II, pp. 95-96).

However, according to Oviedo, the Taíno did not apply the term tabaco to the tobacco plant, but to an Y-shaped tube which he believed the Indians used to inhale tobacco smoke through their nostrils « in order to go out of their senses » by putting the end of the tube " in the smoke of the burning herb » (Oviedo, in Schleiffer 1973, pp. 138-139 ; see also Humboldt, 1852-1853, I, p. 329). This is contradicted by Las Casas (in Schleiffer 1973, pp. 79-80), who indicates that this tubical instrument was employed for sniffing powdered substances with hallucinogenic properties during ritual gatherings, rather than for inhaling fumes. It is generally assumed that, depending on the occasion, during these so-called cohoba ceremonies the Taino caciques or shamans (behiques) either took tobacco or yopa, i.e. the crushed seeds of a leguminous tree (Anadenanthera peregrina), in order to get into a trance during which their souls were able to contact the spirit world (see Lovén 1935, pp. 387-390, 397-398 ; Pané 1999, pp. 15, 21, 25-26 ; Reichel-Dolmatoff 1975, pp. 5-9, 227-229 ; StevensArroyo 1988, pp. 117-119, 122-124 ; Wassén \& Holmstedt 1963 ; Wilbert 1987, pp. 16, 18, 54). Moreover, according to Las Casas again, in his time the word tabaco was applied to the long, tube-shaped cigars of rolled tobacco leaves which the Taíno shamans were accustomed to smoke for healing purposes and commoners for relaxation (see also Columbus 1992, pp. 65, 70 ; Wassén 1964).

To add to the confusion, it is well possible that the Spanish did not adopt the word tabaco from the Taíno at all. In the early-fifteenth century, thus long before the European discovery of the Americas, a similarly sounding noun was known in both Spanish and Italian, denoting particular medicinal herbs, some of which caused euphoria and others dizziness. It is generally assumed that this word, spelled variously as tabaca, tabauco and atabaca in the documentary sources, is derived from a medieval Arab word, tabbâq or tubbâq (Corominas 1954, IV, pp. 318-321) ${ }^{2}$. This suggests that rather than adopting a Taino loanword, which at any rate was not used to indicate the tobacco plant as such by the Indians of the Greater Antilles, the Spanish applied an existing Old World term, used for denoting herbs causing similar effects as tobacco ${ }^{3}$. Whatever its origin, by the early 1500 s the word tabaco was firmly incorporated in the Spanish vocabulary as the name of the tobacco plant and from Spanish it spread to all other European languages. In the time of Oviedo, who arrived in Hispaniola as late as 1512, i.e. after most of the Taino had died (Wilson 1990, pp. 8-9), apparently the origin of the name had been forgotten already, even in the West Indies. Most importantly, the Spanish also applied the name tabaco to the cigars of rolled tobacco leaves such as Las Casas and Benzoni (in Schleiffer 1973, pp. 140-141) noted that the Taíno smoked. At present " cigar » is indicated by three words in Spanish, i.e. cigarro, puro and tabaco (e.g. Ernst 1889).

The complicated history of the term tabaco should be kept in mind when assessing the widely varying interpretations of the name Tobago, to be found in the literature. First of all, the etymology of the word tabaco indicates clearly that the name of the island was coined by the Spanish, not by the local Amerindians. This is shown also by the fact that the indigenous peoples of the Lesser Antilles, Trinidad, Tobago, and the mainland of South America had quite different names for Tobago. However, by the mid-sixteenth century Tobago and the Spanish name for the tobacco plant had 
become so firmly linked that in 1577 the Spanish physician Monardes (in Schleiffer 1973 , p. 142) even believed that the word tabaco was derived from the supposedly Amerindian name of the island. His opinion is echoed by several later writers, including Rochefort (1665, pp. 56-57) who thought that the Spanish learned the cultivation of tobacco from the Carib Indians living in Tobago at the time of the discovery. A similarly mistaken line of reasoning is followed by Dauxion-Lavaysse (1820, p. 341) and, more recently, by Goslinga (1971, pp. 433-434). In this respect it is noteworthy that the indigenous Amerindians had names for the tobacco plant, quite different from those used by the Spanish and the Taino. The Kalina (Caribs) and Lokono (Arawaks) of the mainland and Trinidad called it taman (tamun) and ióri (iuri), respectively, while the Kalinago (Island Caribs) of the Windward Islands used the term iouli, which is cognate to the Arawak word (Anonymous 1928, p. 264 ; De Goeje 1939, p. 66 ; Lovén 1935, pp. 387, 389 ; Taylor 1977, pp. 19, 23).

Another explanation of the name Tobago first appeared in the literature when Reeves $(1749$, p. 24) suggested that the island has been called after the Y-shaped sniffing tube of the Taíno, erroneously named tabaco by Oviedo, as Tobago's form would closely resemble that of the instrument. This interpretation is repeated by numerous later writers, including Fowler (1774, p. 8), Young (1807-1812, p. 2), Martin (1836, I, p. 232), Woodcock (1867, p. 19), and, in the twentieth century, by Aspinall (1934, pp. 114-115), Anderson (1970, p. 47), Ottley (1970, p. 29), and Archibald (1987-1995, I, p. XI). It is quite obvious that this opinion is just as fallacious as the previous one discussed. By no stretch of imagination the island's form can be likened to an Y, of course. However, by attempting to explain the process of naming, Reeves hits the right trail to a satisfactory interpretation of the toponym. If seen from the ocean, namely, the appearance of Tobago resembles that of the long, fat Taíno cigar which was called tabaco by the Spanish. This likeliness is caused by the island's contour which from almost level in the southwestern part of Tobago slowly rises to reach an almost continuous summit in the Main Ridge area in order to descend abruptly and almost vertically to the sea in the northeasternmost portion of the island. The dark brown to black appearance of the Main Ridge precipices in parts of the island undoubtedly further added to the resemblance.

We may conclude that the name Tobago represents a descriptive toponym, coined by some unknown Spanish sailor, possibly a slaver from Hispaniola, who passed by the island in the first decade of the sixteenth century and called it Tabaco as its contour reminded him of the cigars the Taino were accustomed to smoke. The resultant European association of Tobago with tobacco may have influenced the island's course of history to a certain extent. Indeed, it can be suggested that the first colonization attempts of Tobago by the Spanish, English, Dutch and Courlanders (Latvians), which were initiated almost a century after the island received its name, were stimulated not only by its crucial strategic position well to the windward of almost all of the other islands of the Lesser Antilles and by Tobago's fine climatic conditions and excellent natural harbours, but perhaps also by the belief that tobacco would grow better in Tabaco island than anywhere else in the West Indies.

As noted above, the Amerindians of Tobago itself and neighbouring islands had quite different names for Tobago. Two of these have been recorded in the 
documentary sources. In the 1620s the Spanish writer Vázquez de Espinosa noted that "Tobago is called Urupaina in the Indian language, meaning big snail », adding that the island is « inhabited by Carib Indians, who used to ravage the island of Trinidad » (Espinosa 1942, p. 57). In the mid-seventeenth century Tobago is indeed reported to be inhabited by Amerindians ethnically belonging to the Cariban-speaking Kalina, i.e. Caribs who formerly lived also in North Trinidad and still inhabit parts of the Orinoco Valley and the Guianas (Boomert 1986, p. 14 ; Pelleprat 1965 , pp. 36, 83-84). This would suggest that the name Urupaina represents a Cariban word. If so, it may be related to oruape, a generic term documented in 1789 as the Kalina word for «large snail» (Anonymous 1928, p. 221). Consequently, it can conjecturally be suggested that, like the Spanish, the Kalina Indians were struck by the characteristic contour of Tobago, seen from the ocean, which reminded them of the outlines of the large marine gastropods to be found in the Caribbean.

The second name for Tobago, to be found in the historic literature, was recorded by the French missionary Raymond Breton who worked among the Kalinago (Island Caribs) of the Windward Islands, especially Dominica and Martinique, in the midseventeenth century. Breton (1999, pp. 204, 269, 1900, p. 373) notes that the Island Caribs called Tobago Aloubaéra, but does not explain the meaning of this name ${ }^{4}$. The present author first suggested that the name may be related to beléuera or beréuera, i.e. the Island Carib name of the West Indian Crown Conch or Black Conch (Melongena melongena), an edible marine gastropod which is found in mangrove swamps throughout the Caribbean. This name appears to be a compound of béle, "soft, sticky ", and éuera, «tool, penis » (Taylor 1956 ; see Breton 1999, pp. 37, 114, 165), thus referring to the animal itself, not to its shell, and, consequently, its etymology would be remarkably similar to that of the name Urupaina (Boomert 2000, p. 20). In this respect it should be noted that the Island Caribs spoke a basically Arawakan language, quite comparable to Taino and Lokono, of which the male register included a large number of Kalina loanwords.

However, Breton (1900, p. 90) mentions the same word he records as the Island Carib name for Tobago, in a quite different context when stating that « la couleuvre, ou escarboucle» of Dominica is known as alloüebéra (also Breton 1999, p. 17). Elsewhere he notes that the Amerindians of the Windwards paint their canoes with red pigment, which they believe to represent the excrement of a " grosse couleuvre qu'ils appellent oloubera qui est dans une caverne effroyable » (Breton 1978, p. 70 ; also Breton 1900, p. 173). This monstrous snake is a mythical animal which takes a prominent place in Island Carib cosmology. Apart from Breton, its presumed existence was documented by seventeenth-century chroniclers such as Bouton, Provins and Rochefort among the inhabitants of Dominica, Martinique and St Vincent (Allaire 1981). The myth in question refers to a large snake or dragon that can make itself large or small at will. Moreover, it bears a bright, red jewel or carbuncle on its forehead which is moveable like a human eye-lid and is exposed when the snake is drinking, illuminating the surroundings. This bejewelled snake (boa) lives in a twin mountain inside a deep cavern where it deposits a red excrement, killing anyone who approaches it unless one has fasted and abstained from sexual intercourse for at least three days. 
As late as the 1940s the belief in this monstrous snake was still extant among the Island Caribs of Dominica. The bejewelled snake, known as the Master Boa (Maitre Tête-Chien), is described as " big, big, big », wearing " a diamond crest on its head » and crowing " just like a cock ». It was supposed to live in a cave, situated in the hills of the northern part of the island, where a gigantic stone heap, forming a kind of natural stairway, is attributed to its activities (Taylor 1952a). Various other tales, recorded in Dominica and among the Garifuna of Belize, i.e. the descendants of the Black Caribs of St Vincent, can be associated with the myth of the bejewelled snake. One of them features a child with a human head and snake's body, called Bakamu, which was born to a woman who had an affair with a boa. The child became so demanding that she put him into a large conch and fled. Chasing her, he was swept away by a flood and became a constellation which takes the form of a snake with a human head and a big red eye (Gullick 1985, pp. 100-101 ; Petitjean Roget 1994, 1995 ; Robiou-Lamarche 1990 ; Taylor 1938, 1945, 1946, 1951, pp. 143, 153-154, 1952a, 1977, pp. 240-242). A related tale is known from St Vincent. This narrates the story of Racumon, one of the first Caribs, who took the shape of a large snake with human head and now forms a star (De la Borde 1886). Finally, Breton (1978, p. 52) refers to Kalinago, the first Carib, who was metamorphosed into a monstrous fish or boa, named Acaïouman, " which still lives in the rivers ». Indeed, as late as the 1950s in Dominica a river called Akáyu was known to represent the abode of the Maitre Tête-Chien (Taylor 1980).

All of this suggests that the Island Caribs called Tobago, Aloubaéra, after the giant bejewelled snake, alloüebéra or oloubera, that took such a prominent position in their mythology. Clearly, they believed that the outline of Tobago closely resembled that of the monstrous serpent, just as their relatives the Kalina and the Spanish compared the island with the outlines of a conch next to a cigar, respectively. The mountainous northeastern part of Tobago was apparently believed to represent the head of the animal while the rest of the island symbolized its body. If indeed Tobago was taken by the Island Caribs to personify the Antillean bejewelled snake, an Amerindian tale on the island, recorded by Rochefort in the mid-seventeenth century, becomes intelligible as referring to this mythical serpent. According to Rochefort (1665, pp. 116-117), the Caraibes called a mountain in Tobago's northeastern portion the " mountain of the devil », as " fires that illuminate in the night » are often to be seen here. The Indians were afraid of this phenomenon, which they attributed to malevolent spirits.

As the northeastern part of Tobago would have symbolized the head of the bejewelled snake, the " fires " observed by the Indians in this part of the island may have referred to the bright, red eye on the forehead of the mythical animal which, if exposed, is believed to have illuminated its surroundings ${ }^{5}$. Rochefort supposed that the « fires » were caused by naturally occurring deposits of sulphur, which were lit due to the heat of the sun in the daytime. Although obviously this explanation should be rejected, it is well possible that at times the sun's reflection on the occasionally bare outcrops of phyllitic sericite schists which predominate the rocks of the northern third of Tobago (Maxwell 1948 ; Rowley \& Roobol 1978), gives the impression of a source of light in this area. It may have reminded the Amerindians of the bright jewel on the forehead of the Antillean monstrous snake. 


\section{NOTES}

1. The first recorded variant of the island's name is mistakenly spelled as Cobaco or Cabaco by Sauer (1966, p. 193), Jesse (1963) and Nardin (1962).

2. The resemblance between the word « tobacco » and Island Carib bitábaco, « thy shut-eye », noted by Taylor (1952b), appears to be accidental.

3. It should be kept in mind that the Taino probably used Nicotiana rustica, which has the highest nicotine content of all tobacco species, in order to intoxicate themselves and reach an ecstatic-visionary state (Furst 1992).

4. De Goeje (1936) mentions a Spanish variant of this name, Arubeira, but does not specify its source.

5. Even today there are reminiscences of tales possibly related to the myth of the bejewelled snake among the peasant and fishermen population of Tobago. According to Caesar (1984), there exists a belief in Plymouth on Tobago's leeward coast that there lives a cock with fire on its head on the beach of Great Courland Bay just south of the village. This cock would represent the spirit of old soldiers who were killed and buried with treasure which it is guarding.

\section{REFERENCES}

Allaire, Louis, 1981. - « The Saurian pineal eye in Antillean art and mythology », Journal of Latin American Lore, 7, pp. 3-22.

Anderson, Edgar, 1970. - Senie Kurzemmieki Amerika un Tobago kolonizacija. Daugava, Stockholm.

Anonymous, ca 1560. - [Mapa de la Provincia de los Aruacas], Spanish manuscript map, reproduced in: Hermann González Oropeza (ed.), Atlas de la historia cartográfica de Venezuela, 1983, Lam. XXI, Enzo Papi, Caracas.

ANonymous, 1642. - Tobago. English manuscript map, reproduced in : Edgar Anderson 1970, Senie Kurzemnieki Amerika un Tobago kolonizacija, p. 80, Daugava, Stockholm.

Anonymous, 1928. - «Vocabulario de Español a Caribe..., 1789 », in : Catálogo de la Real Biblioteca, I, Mamuscritos : Lenguas de América, vol. I, pp. 197-212, Madrid [orig. written 1789].

Archibald, R. Douglas, 1987-1995. - Tobago : " Melancholy Isle », 2 vol., Westindiana \& University of the West Indies, Port-of-Spain/St Augustine.

Aspinall, Sir Algernon, 1934. - A Wayfarer in the West Indies, 3rd ed., London.

Boomert, Arie, 1986. - « The Cayo complex of St. Vincent : Ethnohistorical and archaeological aspects of the Island Carib problem », Antropológica, 66, pp. 3-68.

—, 2000. - Trinidad, Tobago and the Lower Orinoco Interaction Sphere, Cairi Publications, Alkmaar.

Breton, Père Raymond, 1900. - Dictionaire Français-Caraibe, Platzmann, Leipzig [first publ. Auxerre 1666].

—, 1978. — Relations de l'Ile de la Guadeloupe, Société d'Histoire de la Guadeloupe, Basse-Terre [orig. written 1647-1656].

—, 1999. — Dictionnaire caraibe-français, Marina Besada Paisa (ed.), Karthala/IRD, Paris [first publ. Auxerre 1665]. 
BRINTON, D.G., 1871. - « The Arawack language of Guiana in its linguistic and ethnological relations », Transactions of the American Philosophical Society, 14, pp. 427-444.

CAESAR, Erol, 1984. - «Superstitions among Tobago fisherfolk», in : Report conference on culture and the cultural heritage of Tobago, Mt Irvine Bay 1984, pp. 63-64.

CDU, 1885-1932. - Colección de documentos inéditos relativos al descubrimiento, conquista y organización de las antiguas posesiones españolas de ultramar, 25 vol., Madrid.

Columbus, Ferdinand, 1992. - The life of the Admiral Christopher Columbus by his son Ferdinand, Benjamin Keen (ed. \& transl. from the Italian), 2nd ed., Rutgers University Press, New Brunswick, N. J. [first publ. Venice 1571].

Corominas, J., 1954. - Diccionario crítico etimológico de la lengua Castellana, 4 vol., Francke, Bern.

Dauxion-LAVAysSe, Jean-François, 1820. - A statistical, commercial, and political description of Venezuela, Trinidad, Margarita, and Tobago, transl. from the French, Whittaker, London.

De Goese, Claudius H., 1936. - « De namen der Antillen », West-Indische Gids, 18, pp. 33-37.

—, 1939. - « Nouvel examen des langues des Antilles », Journal de la Société des Américanistes, 31 , pp. 1-120.

De LA BoRde, Sieur, 1886. - « History of the Origin, Customs, Wars, and Travels of the Caribs, Savages of the Antilles in America ", G. J. A. Bosch-Reitz (transl. from the French), Timehri, 5, pp. 224-254 [first publ. Paris 1674].

De LAET, Johannes, 1931-1937. - Iaerlyck Verhael van de Verrichtinghen der Geoctroyeerde West-Indische Compagnie, 4 vol., S. P. L. L'Honoré Naber (ed.), Werken van de Linschoten Vereeniging, 34, 35, 37, 40, 's-Gravenhage [orig. written 1623-1636].

Devas, Raymond P., 1974. - A history of the island of Grenada, 1498-1796, St George's, Grenada.

DudLEY, Sir Robert, 1646. - [Guiana], in : Arcano del Mare, America XIII, Firenze, Italian map, reproduced in : G. F. Warner (ed.) 1899, The voyage of Robert Dudley, [...] to the West Indies, 1594-1595, Map A, Hakluyt Society 2:3, London.

ERnSt, Adolfo, 1889. - «On the etymology of the word tobacco », American Anthropologist, 2, pp. 133-142.

Espinosa, Antonio Vázquez de, 1942. - Compendium and description of the West Indies, C. Upton Clark (ed. \& transl. from the Spanish), Smithsonian Miscellaneous Collections, 102, Washington, D. C. [orig. written ca 1628-1629].

FrIEDERICI, Georg, 1960. - Amerikanistisches Wörterbuch und Hilfswörterbuch für den Amerikanisten : Deutsch-Spanisch-Englisch, Abhandlungen aus dem Gebiet der Auslandskunde, Reihe B, Band 53, Universität Hamburg, Cram \& De Ruyter, Hamburg.

FowlER, John, 1774. - A summary account of the present flourishing state of the respectable colony of Tobago in the British West Indies, London.

Furst, Peter T., 1992. - « Tobacco ", in : Silvio A. Bedini (ed.), The Christopher Columbus Encyclopedia, vol. I, pp. 279-281, Simon \& Schuster, New York.

Goslinga, Cornelis Ch., 1971. - The Dutch in the Caribbean and on the Wild Coast 1580-1680, Van Gorcum, Assen.

Gullick, Charles J. M. R. C., 1985. - Myths of a minority : The changing traditions of the Vincentian Caribs, Van Gorcum, Assen.

Gumilla, Padre José, 1963. - El Orinoco Ilustrado y Defendido, José Nucete-Sardi (ed.), 2 vol., Biblioteca de la Academia Nacional de la Historia, 68, Caracas [first publ. Madrid 1741]. 
Honem, Diego (?), ca 1540. - [Map of the Gulf of Mexico and the Caribbean], Spanish manuscript map, partially reproduced in : Hermann González Oropeza (ed.), 1983, Atlas de la historia cartográfica de Venezuela, Lam. XIX, Enzo Papi, Caracas.

Humboldt, Baron Alexander von, 1852-1853. - Personal narrative of travels to the Equinoctial regions of America, during the years 1799-1804, Thomassina Ross (ed. \& transl. from the French), 3 vol., London.

JesSe, Father C., 1963. - «The Spanish Cedula of December 23, 1511, on the subject of the Caribs ", Caribbean Quarterly, 9 (3), pp. 22-32.

Jiménez G., Morella A., 1986. - La esclavitud indigena en Venezuela (siglo xVI), Biblioteca de la Academia Nacional de la Historia, 185, Caracas.

KeYmis, Laurence, 1904. - « A relation of the second voyage to Guiana, performed and written in the yeere 1596 », in : Richard Hakluyt, The Principal Navigations Voyages Traffiques \& Discoveries of the English Nation, vol. X, pp. 441-495, MacLehose, Glasgow [first publ. London 1599].

KONETZKE, Richard (ed.), 1953-1962. - Colección de documentos para la historia de la formación social de Hispanoamérica 1493-1810, 3 vol., Consejo Superior de Investigaciones Científicas, Madrid.

Las Casas, Bartolomé de, 1957-1961. - Historia de las Indias, J. Pérez de Tudela Bueso (ed.), 2 vol., Biblioteca de Autores Españoles, 95-96, Madrid [orig. written 1520-1561].

LovéN, Sven, 1935. - Origins of the Tainan culture, West Indies, Elander, Göteborg.

Martin, Robert M., 1836. - History of the West Indies comprising Jamaica, Trinidad, Honduras, Tobago, Grenada, the Bahamas, and the Virgin Islands, vol. I, London.

Maxwell, John C., 1948. - "Geology of Tobago, British West Indies ", Bulletin of the Geological Society of America, 59, pp. 801-854.

Morison, Samuel E., 1942. - Christopher Columbus: Admiral of the Ocean Sea, 2 vol., Little/Brown, Boston.

—, 1955. - Christopher Columbus, Mariner, New American Library, New York.

Morison, Samuel E. (ed.), 1963. - Journals and other documents on the life and voyages of Christopher Columbus, Heritage Press, New York.

Morison, Samuel E., \& M. OBREgón, 1964. - The Caribbean as Columbus saw it, Little/Brown, Boston.

Nardin, Jean-Claude, 1962. - «Sur le nom de l'île de Tabago », Caribbean Studies, 2 (2), pp. 31-34.

Отте, Enrique (ed.), 1967. - Cedularios de la monarquía española de Margarita, Nueva Andalucia y Caracas (1553-1604), Caracas.

Ottley, Carlton R., 1970. - A history of place-names in Trinidad \& Tobago, Ottley, Diego Martin.

Oviedo y VALDÉs, Gonzalo Fernández de, ca 1545, - [Mapa del rio de Huyapari], Spanish manuscript map, reproduced in : Gonzalo Fernández de Oviedo y Valdés, 1959, Historia general y natural de las Indias, Islas y Tierra Firme del Mar Océano, Juan Pérez de Tudela Bueso (ed.), 5 vol., vol. V, Lam. VII, Biblioteca de Autores Españoles 117-121, Madrid [orig. written 1535-1547].

Oxford English Dictionary, 1971. - The compact edition of the Oxford English Dictionary, 2 vol., Oxford. 
Pané, Fray Ramón, 1999. - An Account of the Antiquities of the Indians, José J. Arrom (ed.) \& Susan C. Griswold (transl. from the Spanish), Duke University Press, Durham/London [orig. written 1493-1498].

Pelleprat, Père Pierre, 1965. - Relato de las misiones de los padres de la Compañía de Jesús en las Islas y en Tierra Firme de América Meridional, P. José del Rey (ed. \& transl. from the French), Biblioteca de la Academia Nacional de la Historia, 77, Caracas [first publ. Paris 1655].

Petitjean-Roget, Henri, 1994. — «Éléments pour une étude comparée des mythologies Taïnos et Caraïbes insulaires (Kalinas) des Antilles », Espace Caraïbe, 2, pp. 91-107.

—, 1995. - « Les calebasses peintes, la poterie et l'arc-en-ciel chez les Caraïbes insulaires », Proceedings of the Sixteenth International Congress for Caribbean Archaeology, Guadeloupe 1995, vol. I, pp. 159-175.

ReEves, W., 1749. - Tobago ; Or; a Geographical Description, Natural and Civil History... of that Famous Island, Reeves, London.

Reichel-Dolmatoff, Gerardo, 1975. - The shaman and the jaguar : A study of narcotic drugs among the Indians of Colombia, Temple University Press, Philadelphia.

RiBEIRo, Diogo (Diego) de, 1529. - [Map of the World], Spanish manuscript map, partially reproduced in : C. Koeman (ed.), 1973, Links with the past : The history of cartography of Suriname 1500-1971, Fig. 1, Theatrum Orbis Terrarum, Amsterdam.

Robiou-Lamarche, Sebastián, 1990. — «Island Carib mythology and astronomy », Latin American Indian Literatures Journal, 6, pp. 36-54.

Rochefort, Charles de, 1665. - Le Tableau de l'Isle de Tabago, ou de la Nouvelle Oüalchre. L'une des Isles Antilles de l'Amerique, Jean le Carpentier, Leyde.

Rowley, Keith C., \& M. John Roobol, 1978. — « Geochemistry and age of the Tobago igneous rocks », Geologie en Mijnbouw, 57 (2), pp. 315-318.

SAuer, Carl O., 1966. - The early Spanish Main, University of California Press, Berkeley/Los Angeles.

SCHLeIfFer, Hedwig (ed.), 1973. - Sacred narcotic plants of the New World Indians : An anthology of texts from the 16th century to date, New York/London.

Strvens-Arroyo, Antonio M., 1988. - Cave of the Jagua: The mythological world of the Tainos, University of New Mexico Press, Albuquerque.

TAYLOR, Douglas M., 1938. - " The Caribs of Dominica », Smithsonian Institution, Bureau of American Ethnology, Bulletin 119, pp. 103-160.

—, 1945. — « Carib folk-beliefs and customs from Dominica, B. W. I. », Southwestern Journal of Anthropology, 1, pp. 507-530.

—, 1946. - " Notes on the star lore of the Caribbees », American Anthropologist, 48, pp. 215222.

—, 1951. - The Black Carib of British Honduras, Viking Fund Publications in Anthropology, 17, New York.

—, 1952a. — « Tales and legends of the Dominica Caribs », Journal of American Folklore, 65, pp. 267-279.

- 1952b. - "A note on the derivation of the word " tobacco" ", American Anthropologist, 54, pp. $278-279$.

—, 1956. - « Names on Dominica », West-Indische Gids, 36, pp. 121-124.

—, 1958. — « Names on Saint Vincent », West-Indische Gids, 38, pp. 106-110. 
—, 1977. - Languages of the West Indies, Johns Hopkins University Press, Baltimore/London.

—, 1980. — «A note on the derivation of the word cayman ", International Journal of American Linguistics, 46, pp. 47-48.

WASsÉN, S. Henry, 1964. - «Some general viewpoints in the study of native drugs especially from the West Indies and South America ", Ethnos, 1-2, pp. 97-120.

Wassén, S. Henry, \& Bo Holmstedt, 1963. - « The use of paricá, an ethnological and pharmacological review "), Ethnos, 28 (1), pp. 5-45.

WiLBert, Johannes, 1987. - Tobacco and shamanism in South America, Yale University Press, New Haven/London.

Wilson, Samuel M., 1990. - Hispaniola: Caribbean chiefdoms in the age of Columbus, University of Alabama Press, Tuscaloosa/London.

Young, Sir William, 1807-1812. - A Historical, Statistical, and Descriptive Account of the Island of Tobago, University of the West Indies, St Augustine, Trinidad (manuscript).

Woodcock, Henry I., 1867. - A History of Tobago, The author, Ayr. 